\title{
Faktor Perilaku yang Berhubungan dengan Hasil Pemeriksaan Jentik Pasca Keberadaan Surveilans Angka Bebas Jentik di Kecamatan Tembalang Kota Semarang
}

\author{
Behavior Factors Associated with Results of Post Larvae Examination of Surveilans \\ in Tembalang District, Semarang City
}

\author{
Diana Andriyani Pratamawati*, Widiarti, Wiwik Trapsilowati, Riyani Setiyaningsih \\ Balai Besar Penelitian dan Pengembangan Vektor dan Reservoir Penyakit Salatiga \\ Jalan Hasanudin No.123 Salatiga, Jawa Tengah, Indonesia \\ *E_mail: pratamawati@gmail.com
}

Received date: 07-02-2019, Revised date: 12-09-2019, Accepted date: 11-10-2019

\begin{abstract}
ABSTRAK
Kecamatan Tembalang menjadi wilayah dengan Incidence Rate (IR) DBD tertinggi di Kota Semarang tahun 2014-2016. Incidence rate DBD di Kecamatan Tembalang pada tahun 2016 sebesar 166,89/100.000 penduduk dengan Case Fatality Rate (CFR) 1,02\%. Pemerintah Kota Semarang telah menjalankan Perda No.5 tahun 2010 tentang pengendalian DBD dengan dibentuknya petugas khusus pemantauan jentik yaitu Kader Semantik (Semarang Bebas Jentik) dan Gasurkes (Petugas Surveilans Kesehatan) untuk melakukan pemantauan jentik rutin serta mensosialisasikan Pemberantasan Sarang Nyamuk (PSN)-3M Plus. Namun, kasus DBD di Kecamatan Tembalang masih terus ada. Tujuan penelitian ini untuk mengidentifikasi faktor perilaku yang berhubungan dengan hasil pemeriksaan jentik di Kecamatan Tembalang Kota Semarang. Jenis penelitian ini adalah cross sectional. Sampel diambil secara kuota dengan jumlah 100 responden. Kriteria sampel yang diambil adalah kasus DBD terbaru yang tercatat di Data Dinas Kesehatan Kota Semarang (Januari s.d September 2017) serta satu tetangganya yang seumur namun tidak sakit DBD pada periode yang sama. Data dianalisis menggunakan uji chi-square. Hasil penelitian menunjukkan faktor perilaku melakukan pemantauan jentik secara rutin berhubungan dengan hasil pemeriksaan jentik $(p<0,05)$ dengan faktor risiko OR $=5,02$ serta dari hasil observasi diperoleh ABJ di Kecamatan Tembalang sebesar $89 \%$ pada tahun 2017. Hal ini perlu menjadi perhatian tambahan dalam prosedur pemantauan jentik oleh Semantik dan Gasurkes. Karena semakin lengkap kualitas pemeriksaan jentiknya, maka kejadian DBD dapat dicegah.
\end{abstract}

Kata kunci: jentik, PSN, DBD, Tembalang

\begin{abstract}
Tembalang Subdistrict is still ranked as the first highest IR Dengue in Semarang City in 2014-2016. Incidence rate of dengue in Tembalang Sub District in 2016 was Dengue hemorrhagic fever (DHF) IR 166.89/100,000 population with Case Fatality Rate (CFR) 1.02\%. The Semarang City Government has implemented PERDA No.5 of 2010 concerning DHF control with the establishment of special larvae monitoring officers namely Semantik (Semarang Bebas Jentik) and Gasurkes (Health Surveillance Officer) to conduct routine larval monitoring and socialize PSN-3M Plus. However, dengue cases in Tembalang District continue to exist.The purpose of the study was to identify behavioral factors related to monitoring larva presence in Tembalang District, Semarang City. This study is based on the cross sectional method, with quota sampling was used to recruit 100 respondents. The criteria for the case were the latest DHF cases recorded in the Semarang City Health Office Data (January to September 2017). Samples were taken in quota with 100 respondents. Data were analyzed by analytic descriptive using chi-square analysis and odds ratio. The results showed behavioral factors to monitor larvae routinely related to the results of larvae examination $(p<0,05)$ with risk factors OR $=5,02$ and form observations obtained ABJ in Tembalang District by $89 \%$ in 2017. This needs additional attention in the larva monitoring procedure by Semantics and Gasurkes. The more complete the quality of the larvae examination, the existence of larvae can be eradicated, so that the incidence of DHF can be prevented.
\end{abstract}

Keywords: larvae, PSN, DHF, Tembalang 


\section{PENDAHULUAN}

Demam Berdarah Dengue (DBD) adalah penyakit menular yang ditandai umumnya dengan demam tinggi $\left(40^{\circ} \mathrm{C}\right)$ dan jika tidak mendapatkan pengobatan yang adekuat maka akan timbul perdarahan. Demam berdarah dengue ditularkan melalui gigitan nyamuk Aedes aegypti yang hidup di dalam dan di sekitar rumah yang disebabkan oleh virus Dengue. ${ }^{1}$ Jumlah kasus DBD di Indonesia cenderung fluktuatif, berdasarkan data dari Pusat Data dan Informasi Kementerian Kesehatan pada tahun 2015 jumlah penderita DBD sebesar 126.675 orang dengan jumlah kabupaten/kota terjangkit mencapai 436 dari 34 provinsi. $^{2}$ Jumlah penderita DBD meninggal juga berfluktuatif tiap tahunnya namun masih cukup tinggi. Penderita DBD yang meninggal pada tahun 2015 sebesar 1.358 orang, jumlah ini meningkat dari dua tahun sebelumnya. ${ }^{3}$

Incidence Rate (IR) DBD di Jawa Tengah mengalami peningkatan pada tahun 2015 dan tahun 2016 dibandingkan tahun 2014. Incidence Rate DBD pada tahun 2015 sebesar 47,90 per 100.000 penduduk dan tahun 2016 yaitu 43,48 per 100.000 penduduk, sementara IR DBD pada tahun 2014 sebesar 36,24 per 100.000 penduduk. ${ }^{4-6}$ Pada tahun 2014, Kota Semarang menduduki peringkat pertama IR DBD untuk Provinsi Jawa Tengah dengan angka 97,31 kemudian naik kembali menjadi 99,46 pada tahun 2015, meski pada tahun 2016 angkanya turun menjadi 24,41. ${ }^{4-6}$ Case Fatality Rate (CFR) akibat DBD di Kota Semarang pada tahun 2011-2016 cenderung fluktuatif. Angka CFR tahun 2015 sebesar $1,21 \%$ meningkat menjadi $5,13 \%$ pada tahun 2016.

Menurut informasi Dinas Kesehatan Kota Semarang, tiga wilayah kecamatan penyebaran DBD tinggi tahun 2015 di Kota Semarang adalah Kecamatan Tembalang, Banyumanik, dan Ngaliyan. Kecamatan Tembalang masih menempati peringkat pertama IR DBD tertinggi di Kota Semarang tahun 2014-2016 dengan IR DBD tahun 2016 sebesar $166,89 / 100.000$ penduduk dengan
CFR 1,02\%. ${ }^{7}$ Sementara itu, awal tahun 2017 sampai bulan April masih ditemukan kasus DBD sebesar 221 kasus di Kota Semarang. ${ }^{8}$ Bahkan hingga akhir tahun 2017, Kecamatan Tembalang masih menduduki posisi tertinggi kasus DBD di Kota Semarang. ${ }^{7}$

Dalam rangka mengendalikan kasus DBD, Pemerintah Kota Semarang telah mengeluarkan berbagai program yang dikuatkan dalam kebijakan berbentuk Perda No.5 tahun 2010. Peraturan daerah ini berisi aturan pengendalian penyakit DBD yang meliputi serangkaian kegiatan pencegahan dan penanggulangan untuk memutus mata rantai penularan DBD dengan cara melakukan pemberantasan nyamuk dan jentik Ae. aegypti dan Ae. albopictus. Program-progam pengendalian DBD yang dilakukan berdasarkan perda ini antara lain PSN-3M Plus, pemeriksaan jentik, dan penyuluhan kesehatan. ${ }^{9}$ Untuk mendukung kebijakan ini, Pemerintah Kota Semarang telah menjalankan berbagai program pemberantasan sarang nyamuk (PSN). Salah satu program yang mendukung pelaksanaan perda tersebut yaitu pembentukan surveilans vektor/angka bebas jentik (ABJ) dengan program Semarang Anti Jentik (Semantik) dan Petugas Surveilans Kesehatan (Gasurkes). Semantik dengan kegiatannya berupa Jumat Bersih di sebanyak 177 kelurahan dibagikan sirine dari Dinkes Kota Semarang untuk dibunyikan serentak pada hari jumat untuk serentak melakukan PSN. Pelaksana Semantik yaitu petugas pemantau jentik yang melakukan pemantauan jentik secara rutin sebanyak 20 rumah/2 minggu serta dilakukan monitoring dan evaluasi. ${ }^{3,10}$ Program Gasurkes dimulai Bulan Januari 2015 dengan dibiayai Dinkes Kota Semarang, petugasnya adalah tenaga kontrak minimal berpendidikan diploma. ${ }^{11}$ Gasurkes menjadi bagian dari Dinas Kesehatan Kota Semarang namun secara teknis bekerja di tiap kecamatan di Kota Semarang. ${ }^{11}$ Gasurkes memiliki tugas sebagaimana diatur dalam Peraturan Walikota Kota Semarang No.27 B Tahun 2012. ${ }^{12}$ Diketahui Semantik dan Gasurkes ini selain sebagai petugas surveilans 
yang salah satu tugasnya mendampingi pemantauan jentik yang dilakukan oleh masyarakat, juga mempunyai tugas untuk melakukan penyuluhan pengendalian vektor DBD kepada masyarakat serta selalu memperbaharui data angka bebas jentik untuk Dinas Kesehatan Kota Semarang.

Pasca dibentuknya Gasurkes dan Semantik (2015) nilai ABJ Kota Semarang tahun 2015-2018 terus meningkat disertai dengan penurunan jumlah kasus. Keberadaan surveilans vektor/ABJ seperti Semantik dan Gasurkes sesungguhnya sangat penting dalam pengendalian kasus DBD. Sebab, salah satu faktor yang mempengaruhi kejadian DBD adalah kepadatan jentik vektor nyamuk DBD di rumah penduduk yang digambarkan dalam ABJ. Sejak tahun 2015 hingga tahun 2018, Kota Semarang mengalami peningkatan nilai ABJ yang disertai berkurangnya jumlah kasus DBD seperti yang dilihat pada Gambar 1.

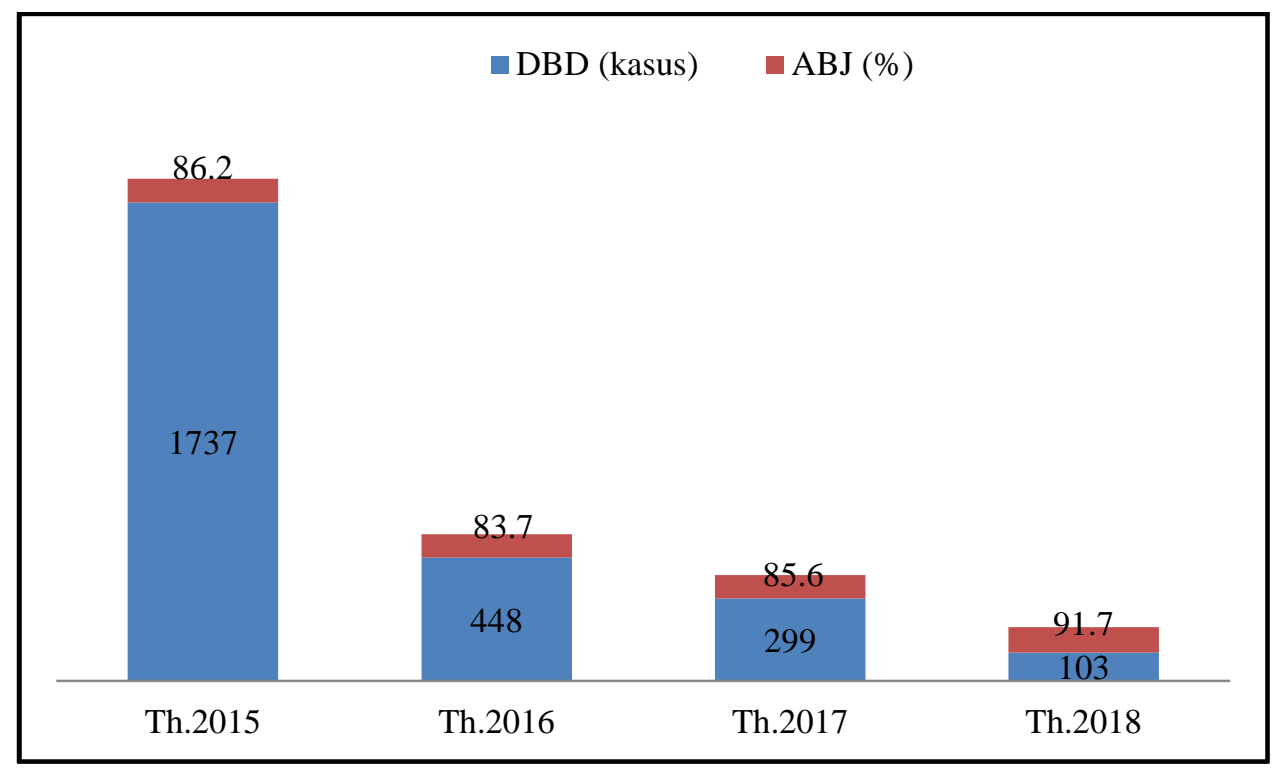

Gambar 1. Grafik Perbandingan Angka Bebas Jentik (ABJ) dengan Jumlah Kasus DBD Tahun 2015-2018 di Kota Semarang ${ }^{13}$

Keberadaaan jentik Ae. aegypti di suatu daerah merupakan indikator terdapatnya populasi nyamuk Ae. aegypti di daerah tersebut. Kepadatan nyamuk Ae. aegypti yang tinggi mempunyai risiko terjadi penularan penyakit DBD. Salah satu indikator yang dapat menggambarkan kepadatan nyamuk yaitu ABJ. Angka Bebas Jentik (ABJ) merupakan salah satu indikator yang paling sering digunakan untuk surveilans vektor. Nilai ABJ menunjukkan indikator rumah yang tidak ditemukan jentik nyamuk di suatu wilayah. ${ }^{14}$ Pemberantasan sarang nyamuk (PSN) yang baik dan benar bertujuan untuk memutus rantai penularan DBD dengan meningkatkan ABJ. ${ }^{15}$ Oleh karena itu, keberadaan surveilans vektor merupakan upaya untuk meningkatkan angka $A B J$ di suatu daerah untuk memutus rantai penularan virus Dengue yang dapat mengakibatkan tingginya kejadian penyakit DBD. ${ }^{16}$

Meski telah ada Semantik dan Gasurkes, data kasus DBD di Kecamatan Tembalang masih berfluktuatif, namun cenderung turun, meski meningkat lagi mulai Bulan Januari 2017. ${ }^{3}$ Kasus DBD di Kecamatan Tembalang yang fluktuatif perlu diwaspadai. Meski berbagai program telah dilaksanakan termasuk adanya petugas surveilans kesehatan untuk ABJ, namun kasus DBD terus ada baik pada usia bayi, anak maupun dewasa. Penelitian ini bertujuan mengidentifikasi faktor-faktor perilaku masyarakat yang berhubungan dengan hasil positif/negatif pemeriksaan jentik di Kecamatan Tembalang pasca adanya petugas 
surveilans ABJ (Semantik dan Gasurkes) di Kecamatan Tembalang Kota Semarang.

\section{METODE}

Penelitian ini dilakukan di Kecamatan Tembalang Kota Semarang pada Bulan November 2017. Jenis penelitian observasional analitik dengan pendekatan cross sectional. Penelitian ini difokuskan kepada faktor perilaku yang berhubungan dengan hasil pemeriksaan jentik dan nilai $\mathrm{ABJ}$ pasca keberadaan petugas pendamping pemantauan jentik di wilayah Kecamatan Tembalang tahun 2017.

Populasi dalam penelitian ini adalah seluruh penduduk di wilayah Kecamatan Tembalang Kota Semarang. Sampel diambil dengan cara sampling kuota. Kuota sampel yang diambil dari perhitungan sampel rumah yang diperiksa dalam survei entomologi DBD yaitu diambil minimal 100 rumah, jumlah ini sesuai dengan standar minimal yang ditetapkan oleh WHO. ${ }^{17,18}$ Sehingga responden yang diwawancara juga sebanyak 100 responden. Kriteria sampel responden yang diambil adalah individu yang sakit DBD yang disebut sampel kasus pada rentang waktu Januari-
September 2017 (50 responden kasus) serta individu tetangga sekitar rumah kasus yang memiliki usia sama dengan kasus dan tidak sakit DBD pada periode tersebut (50 responden non kasus). Basis data kasus yang diwawancarai adalah kasus DBD terbaru yang tercatat di Data Dinas Kesehatan Kota Semarang (Data kasus Januari s.d September 2017). Instrumen penelitian yaitu wawancara dengan kuesioner terstruktur. Daftar pertanyaan dalam kuesioner meliputi observasi kontainer untuk mengetahui $\mathrm{ABJ}$ di Kecamatan Tembalang pasca pemeriksaan rutin surveilans $A B J$ serta kuesioner perilaku pencegahan DBD untuk mengetahui faktorfaktor yang berpengaruh pada pemeriksaan jentik. Data dianalisis menggunakan analisis chi-square.

\section{HASIL}

Berdasarkan hasil penelitian diketahui total responden kasus dan kontrol sejumlah 100 orang (50 kasus dan 50 non kasus). Jumlah responden terbanyak dari Kelurahan Sendangmulyo yaitu 22 orang. Jumlah responden selengkapnya dapat dilihat pada Gambar 2.

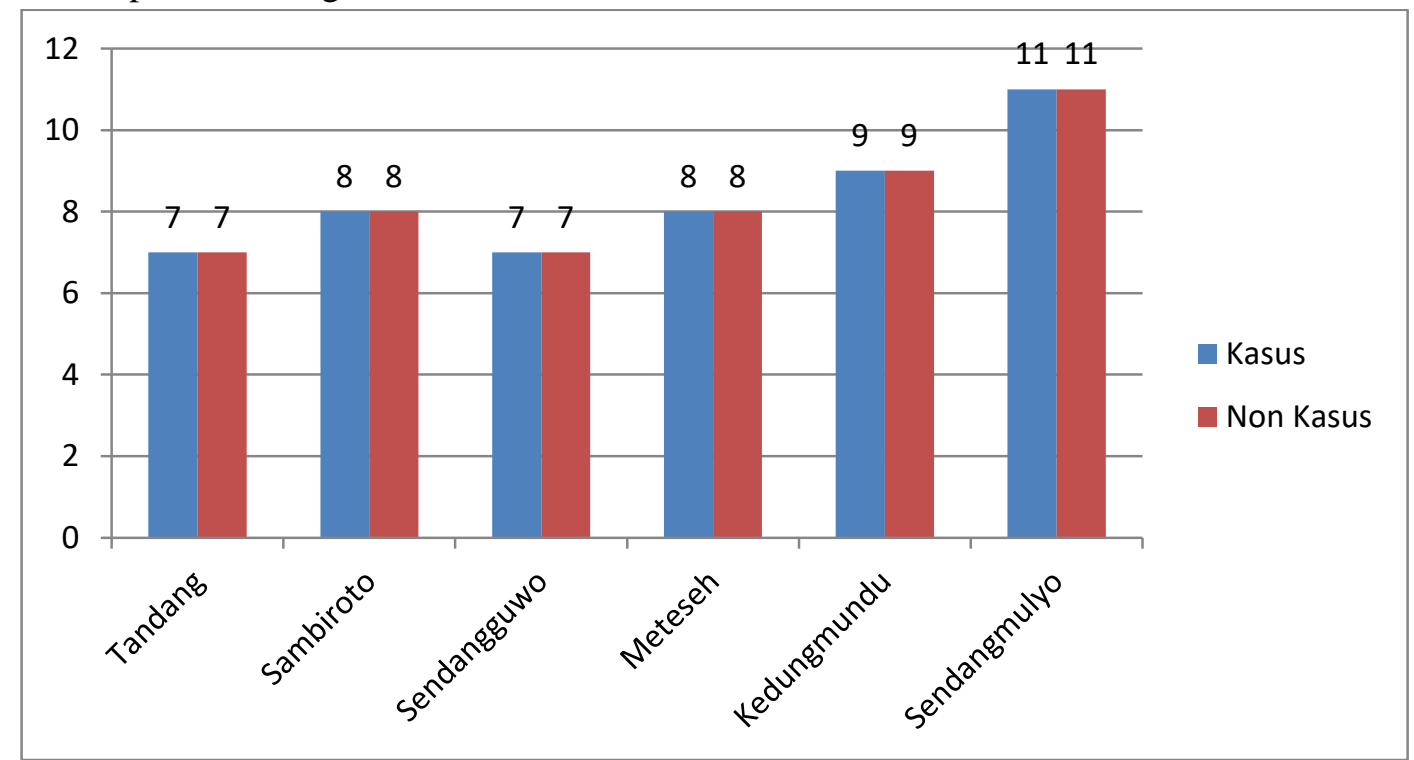

Gambar 2. Distribusi Jumlah Responden Kasus dan Non Kasus Berdasarkan Asal Kelurahan di Kecamatan Tembalang Kota Semarang Tahun 2017 
Jika dilihat dari hasil pemeriksaan jentik pada rumah responden kasus dan non kasus diperoleh hasil jumlah jentik positif masih lebih banyak ditemukan pada kelompok kasus. Berdasarkan hasil pemeriksaan jentik pada responden kasus dan kontrol diperoleh nilai ABJ sebesar 89\%. Hasil selengkapnya dapat dilihat pada Tabel 1.

Tabel 1. Hasil Pemeriksaan Jentik pada Rumah Responden di Kecamatan Tembalang Kota Semarang Tahun 2017

\begin{tabular}{lccc}
\hline \multirow{2}{*}{ Status Responden } & \multicolumn{2}{c}{$\begin{array}{c}\text { Hasil Pemeriksaan Jentik } \\
\text { (rumah responden) }\end{array}$} & Total \\
\cline { 2 - 4 } & Positif & Negatif & \\
\hline Kasus & 6 & 44 & 50 \\
Non Kasus & 5 & 45 & 50 \\
\hline Total & 11 & 89 & 100 \\
\hline
\end{tabular}

Hasil survei jentik di Kecamatan Tembalang tersebut ditemukan masih terdapat jentik pada tampungan air yang sebagian besar berupa bak dan gentong plester semen serta
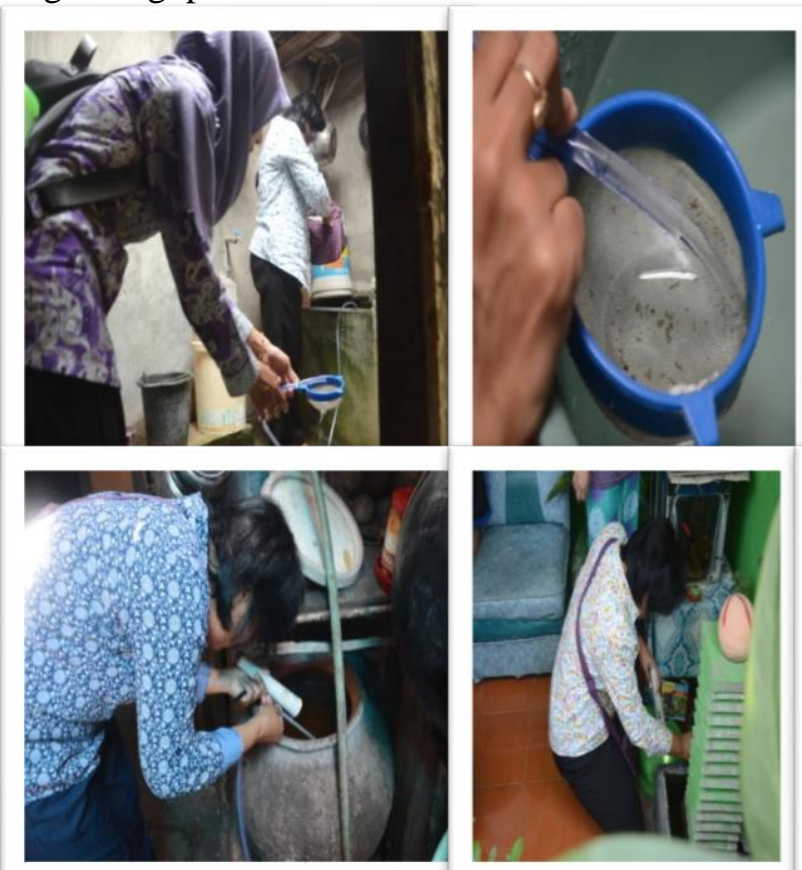

sebagian lainnya ember plastik. Dokumentasi hasil temuan jentik dapat selengkapnya dapat dilihat pada Gambar 3.

Gambar 3. Survei Jentik di Rumah Penduduk di Kelurahan Tandang dan Kelurahan Sambiroto Kecamatan Tembalang Kota Semarang

Karakteristik responden kasus DBD di Kecamatan Tembalang Kota Semarang yang diperoleh pada penelitian ini dapat dilihat bahwa sebagian besar berjenis kelamin perempuan, umur antara 6 s.d 22 tahun, pekerjaan mayoritas sebagai pelajar. Sebagian besar responden kasus DBD, sebelum sakit tidak keluar kota, dan mengetahui ada tetangga sekitar yang juga sakit DBD. Data karakteristik responden kasus DBD selengkapnya dapat dilihat pada Tabel 2 . 
Tabel 2. Karakteristik Responden Kasus DBD di Kecamatan Tembalang Kota Semarang Tahun 2017

\begin{tabular}{|c|c|c|c|}
\hline No. & Karakteristik & $\begin{array}{c}\mathrm{n} \\
(\mathrm{n}=50)\end{array}$ & $\%$ \\
\hline \multirow[t]{3}{*}{1.} & Jenis Kelamin & & \\
\hline & a. Laki-laki & 23 & 46 \\
\hline & b. Perempuan & 27 & 54 \\
\hline \multirow[t]{7}{*}{2.} & Umur & & \\
\hline & 0-5 Tahun & 11 & 22 \\
\hline & 6-12 Tahun & 16 & 32 \\
\hline & 13-22 Tahun & 16 & 32 \\
\hline & 23-45 Tahun & 4 & 8 \\
\hline & $46-65$ & 2 & 4 \\
\hline & $>65$ Tahun & 1 & 2 \\
\hline \multirow[t]{10}{*}{3.} & Pekerjaan & & \\
\hline & Belum Bekerja & 2 & 4 \\
\hline & Belum Sekolah & 4 & 8 \\
\hline & Ibu Rumah Tangga & 3 & 6 \\
\hline & Kuliah/Karyawan & 0 & 0 \\
\hline & Mahasiswa & 4 & 8 \\
\hline & Pegawai Swasta & 1 & 2 \\
\hline & Pelajar & 33 & 66 \\
\hline & Pelayaran & 1 & 2 \\
\hline & Swasta & 2 & 4 \\
\hline \multirow[t]{3}{*}{4.} & Sebelum sakit keluar kota & & \\
\hline & a. $\mathrm{Ya}$ & 12 & 24 \\
\hline & b. Tidak & 38 & 76 \\
\hline \multirow[t]{3}{*}{5.} & $\begin{array}{l}\text { Sekitar rumah ada tetangga/teman sakit } \\
\text { DBD }\end{array}$ & & \\
\hline & a. Ada & 27 & 54 \\
\hline & b. Tidak ada & 22 & 44 \\
\hline
\end{tabular}

Faktor perilaku yang berhubungan dengan hasil pemeriksaan jentik di Kecamatan Tembalang Kota Semarang adalah melakukan pemeriksaan jentik secara rutin di dalam rumah dan sekitarnya. Pada Tabel 5 dapat dilihat bahwa responden sebagian besar melakukan pemeriksaan jentik secara teratur baik di dalam rumah dan sekitarnya (66\%).
Faktor ini berhubungan secara signifikan $(p<0,01)$ dengan hasil pemeriksaan jentik dengan nilai Odd Ratio (OR) sebesar 5,02. Hasil selengkapnya tentang faktor yang berhubungan dengan hasil pemeriksaan jentik di Kecamatan Tembalang Kota Semarang dapat dilihat pada Tabel 3. 
Tabel 3. Faktor-faktor yang Berhubungan dengan Hasil Pemeriksaan Jentik di Kecamatan Tembalang Kota Semarang

\begin{tabular}{|c|c|c|c|c|c|c|c|}
\hline \multirow{2}{*}{\multicolumn{2}{|c|}{$\begin{array}{l}\text { Faktor yang berhubungan dengan hasil } \\
\text { pemeriksaan jentik }\end{array}$}} & \multicolumn{4}{|c|}{$\begin{array}{l}\text { Hasil Pemeriksaan Jentik } \\
(\mathrm{N}=100)\end{array}$} & \multirow{3}{*}{$p$} & \multirow{3}{*}{ Nilai Odd Ratio } \\
\hline & & \multicolumn{2}{|c|}{ Positif } & \multicolumn{2}{|c|}{ Negatif } & & \\
\hline & & $\mathrm{n}$ & $\%$ & $\mathrm{n}$ & $\%$ & & \\
\hline \multirow{2}{*}{$\begin{array}{l}\text { Membersihkan bak mandi } \\
\text { dan TPA paling lama } \\
\text { seminggu sekali }\end{array}$} & $\mathrm{Ya}$ & 11 & 11 & 89 & 89 & \multirow{2}{*}{ Konstan* } & \multirow{2}{*}{ Konstan* } \\
\hline & Tidak & 0 & 0 & 0 & 0 & & \\
\hline \multirow{2}{*}{$\begin{array}{l}\text { Membuang air dan } \\
\text { kotorannya saat menguras } \\
\text { penampungan air tanpa } \\
\text { menyikat dinding bagian } \\
\text { dalam }\end{array}$} & $\mathrm{Ya}$ & 3 & 3 & 8 & 8 & \multirow{2}{*}{0,06} & \multirow{2}{*}{$\begin{array}{l}3,80 \\
\text { (Range: } 0,84- \\
17,23)\end{array}$} \\
\hline & Tidak & 8 & 8 & 81 & 81 & & \\
\hline \multirow{2}{*}{$\begin{array}{l}\text { Pernah melihat jentik } \\
\text { nyamuk penularan DBD di } \\
\text { rumah atau sekitarnya }\end{array}$} & Ya & 8 & 8 & 68 & 68 & \multirow{2}{*}{0,78} & \multirow{2}{*}{$\begin{array}{c}1,21 \\
\text { (Range: } 0,29- \\
4,99) \\
\end{array}$} \\
\hline & Tidak & 3 & 3 & 21 & 21 & & \\
\hline \multirow{2}{*}{$\begin{array}{l}\text { Melakukan pemeriksaan } \\
\text { jentik secara rutin di dalam } \\
\text { rumah dan sekitarnya }\end{array}$} & $\mathrm{Ya}$ & 4 & 4 & 66 & 66 & \multirow{2}{*}{0,01} & \multirow{2}{*}{$\begin{array}{c}5,02 \\
\text { (Range: } 1,34- \\
18,74)\end{array}$} \\
\hline & Tidak & 7 & 7 & 23 & 23 & & \\
\hline \multirow{2}{*}{$\begin{array}{l}\text { Menyikat dinding } \\
\text { penampungan air bagian } \\
\text { dalam saat menguras }\end{array}$} & $\mathrm{Ya}$ & 11 & 11 & 87 & 87 & \multirow{2}{*}{0,62} & \multirow{2}{*}{$\begin{array}{c}1,13 \\
\text { (Range: } 1,05- \\
1,21)\end{array}$} \\
\hline & Tidak & 0 & 0 & 2 & 2 & & \\
\hline \multirow[t]{2}{*}{ Menggunakan larvasida } & Ya & 2 & 2 & 9 & 9 & \multirow{2}{*}{0,42} & \multirow{2}{*}{$\begin{array}{c}0,51 \\
\text { (Range: } 0,09- \\
2,72)\end{array}$} \\
\hline & Tidak & 9 & 9 & 80 & 80 & & \\
\hline \multirow{2}{*}{$\begin{array}{l}\text { Manfaatkan ikan sebagai } \\
\text { pemakan jentik }\end{array}$} & Ya & 5 & 5 & 30 & 30 & \multirow{2}{*}{0,44} & \multirow{2}{*}{$\begin{array}{c}0,61 \\
\text { (Range: } 0,17- \\
2,16)\end{array}$} \\
\hline & Tidak & 6 & 6 & 59 & 59 & & \\
\hline
\end{tabular}

* Ket: Tidak dapat dilakukan uji statistik karena nilainya konstan.

Indikator faktor risiko DBD di Kecamatan Tembalang Kota Semarang antara lain keberadaan kontainer tanaman hias di sekitar rumah yang memungkinkan untuk berkembangbiak nyamuk $(p<0,01$ dan $\mathrm{OR}=$ $0,38)$ dan ruang pencahayaan cukup ( $p<0,01$ dan $\mathrm{OR}=10,22$ ). Keberadaan tanaman hias nyamuk bukan pada tanaman hiasnya, namun pada kontainer tanaman hias yang dapat menjadi tempat habitat nyamuk. Hasil selengkapnya indikasi faktor risiko DBD di Kecamatan Tembalang Kota Semarang dapat dilihat pada Tabel 4. Kondisi rumah responden yang kurang pencahayaan serta ditemukan positif jentik pada kontainer tanaman hias dapat dilihat pada Gambar 3. 
Tabel 4. Indikasi Faktor Risiko DBD di Kecamatan Tembalang Kota Semarang Tahun 2017

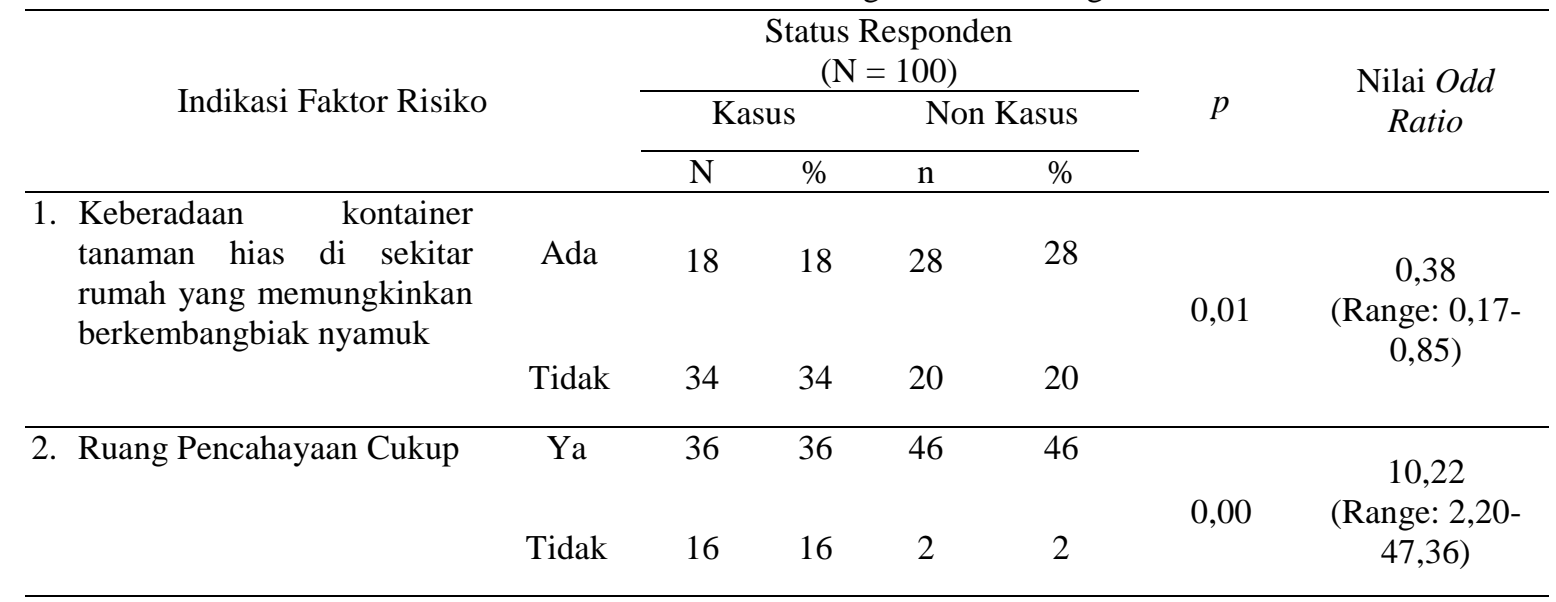

\section{PEMBAHASAN}

Hasil pemeriksaan jentik di Kecamatan Tembalang menunjukkan nilai ABJ sebesar $89 \%$ pada tahun 2017. Angka ini masih dibawah angka standar Kementerian Kesehatan yaitu ABJ diatas $95 \% .{ }^{19}$ Meski telah diperiksa rutin oleh surveilans ABJ yaitu Kader Semantik dan Gasurkes, nilai ABJ di Kecamatan Tembalang masih kurang dari 95\%. Sebagaimana hasil penelitian Putri et al. yaitu ABJ dari pemantauan jentik Gasurkes DBD mempunyai hasil berkisar $80 \%$, yang bermakna, meski ABJ mengalami peningkatan namun masih dibawah standar $(\geq 95 \%) .{ }^{20}$ Keberadaan surveilans ABJ dianggap efektif, namun masih terdapat kendala yang menyebabkan nilai ABJ belum mencapai 95\%. Hasil penelitian Sugiyanto et al. di Kota Semarang menunjukkan partisipasi masyarakat dalam PSN masih rendah, kegiatan PSN belum serempak dan tidak bisa rutin seminggu sekali, serta masih terdapat warga yang tidak mau diperiksa jentik nyamuk di rumahnya khususnya perumahan mewah dan kawasan dekat industri. ${ }^{21}$

Hasil pemeriksaan jentik pasca keberadaan surveilans ABJ di Kecamatan Tembalang dapat dipengaruhi oleh beberapa faktor, antara lain faktor lingkungan dan faktor perilaku individu. Pada penelitian ini, faktor perilaku individu yang terbukti berhubungan dengan hasil pemeriksaan jentik (ABJ) yaitu melakukan pemeriksaan jentik secara rutin di dalam dan di luar rumah. Faktor perilaku yang berhubungan dengan hasil pemeriksaan jentik sangat penting diperhatikan mengingat masih adanya faktor risiko kontainer yang menjadi sumber jentik di Kota Semarang. Hal ini perlu mendapat perhatian karena sumber penularan berada di sekitar rumah. Berdasarkan gambaran karakteristik responden kasus DBD di Kecamatan Tembalang, sebagian besar responden berjenis kelamin perempuan, umur antara 6-22 tahun, pekerjaan mayoritas sebagai pelajar, sebelum sakit sebagian besar tidak keluar kota dan mengetahui ada tetangga sekitar yang juga sakit DBD. Selain itu, analisis ini didukung hasil positif pemeriksaan jentik pada rumah 11 responden. Keadaan Tempat Penampungan Air (TPA) yang bebas jentik di rumah merupakan indikator pencegahan kejadian DBD di rumah tersebut. Semakin rutin melakukan pemantauan jentik secara teratur baik di dalam rumah dan sekitarnya maka semakin kecil terkena DBD. Perilaku masyarakat yang tidak teratur memantau jentik berisiko terkena DBD sebesar 5,02 kali. Meskipun telah ada petugas yang memeriksa rutin yaitu Gasurkes dan Semantik, namun pemeriksaan jentik secara teratur oleh pemilik rumah sangat dibutuhkan. Sebab petugas surveilans ABJ tersebut tidak dapat secara rutin dan setiap hari memeriksa jentik pada setiap rumah. Semakin baik kesadaran pemilik rumah pada kebersihan TPA yang dimilikinya dari jentik maka semakin dini vektor penular DBD dapat diberantas. Sebagaimana hasil penelitian 
Novian menunjukkan adanya hubungan antara kejadian DBD dengan kebiasaan PSN di lingkungan keluarga. $^{22}$ Penelitian Jaya menunjukkan ada hubungan antara menguras dan menutup TPA berhubungan dengan keberadaan larva Ae. aegypti. ${ }^{23}$

Keberadaan jentik di TPA yang lain seperti alas pot, vas bunga berisi air jernih, tandon air, yang terkadang sulit dijangkau atau lepas dari pengamatan perlu mendapat perhatian tambahan dari petugas surveilans ABJ dan masyarakat. Meski telah rutin ada surveilans ABJ di wilayah Kecamatan Tembalang, ternyata jentik nyamuk masih bisa ditemukan pada tempat penampungan tersebut. Hal ini dapat menjadi penyebab kasus DBD masih muncul di suatu daerah meski memiliki kader pemantau jentik aktif dan nilai $A B J$ tinggi. Beberapa hasil penelitian menunjukkan tidak ada hubungan antara kader pemantau jentik dengan nilai ABJ dan keberhasilan PSN. Sebagaimana hasil penelitian Saptarini yang dilakukan di Kelurahan Wonokromo Surabaya, menunjukkan pemberdayaan kader Ibu Pemantau Jentik (Bumantik) tidak ada hubungan dengan nilai Angka Bebas Jentik $(\mathrm{ABJ})$, Container Index (CI) dan 3M Plus. ${ }^{24}$ Penelitian Ariyati di Kota Semarang juga menunjukkan hal yang sejalan yaitu tidak ada hubungan antara kemampuan mengamati jentik dengan kejadian DBD. ${ }^{25}$ Kondisi ini menyebabkan keberadaan surveilans $\mathrm{ABJ}$ nampak belum efektif, karena masih ada peluang hasil pemeriksaan belum mencakup semua TPA yang diperiksa secara rutin di suatu wilayah. Kesadaran masyarakat untuk peka jentik pada TPA di rumah masing-masing serta barang-barang yang dapat menampung air secara terbuka akan sangat mendukung pencapaian nilai ABJ $95 \%$ secara berkelanjutan.

Keterlibatan masyarakat dalam pemeriksaan jentik secara rutin menjadi sangat penting mengingat berdasarkan penelitian ini terdapat dua faktor risiko keberadaan jentik yang berhubungan dengan kejadian DBD di Kecamatan Tembalang, yaitu keberadaan kontainer tanaman hias di sekitar rumah yang memungkinkan untuk berkembangbiak nyamuk serta ruang pencahayaan rumah yang kurang. Semakin banyak kontainer tanaman yang memungkinkan berkembangbiak nyamuk maka semakin tinggi risiko terkena DBD. Berdasarkan penelitian ini, keberadaan kontainer tanaman yang memungkinkan untuk berkembangbiak nyamuk di rumah memiliki risiko 0,38 kali bagi penghuni rumah terkena DBD. Selain itu, rumah dengan ruang pencahayaan kurang juga menjadi faktor risiko DBD di wilayah ini. Semakin tercukupinya ruang pencahayaan di rumah maka semakin baik perlindungan penghuninya dari terkena DBD. Sebab, nyamuk vektor DBD sangat menyukai tempat-tempat yang gelap terhindar dari cahaya. Kecukupan cahaya dalam rumah berpotensi risiko 10,22 terhadap penghuninya terkena DBD. ${ }^{26,27}$ Baik petugas maupun masyarakat sendiri perlu memberikan perhatian lebih pada kontainer keberadaan tanaman hias di sekitar rumah yang memungkinkan nyamuk berkembangbiak. Selain itu, rumah-rumah dengan pencahayaan yang kurang juga berpotensi sebagai tempat istirahat nyamuk potensial. Karena penghuni pada rumah yang kurang pencahayaan akan cenderung kurang teliti dalam memantau keberadaan jentik pada TPA di dalam rumahnya. Faktor risiko pencahayaan rumah yang kurang, beberapa ditemukan di daerah endemis DBD, sebagaimana hasil penelitian Astuti (2018) menunjukkan intensitas cahaya terbukti berhubungan dengan kepadatan larva Aedes sp. pada lingkungan fisik sekolah di Kabupaten Bantul. ${ }^{28}$ Hasil penelitian lain di Kabupaten Pangkep juga menunjukkan bahwa mengupayakan pencahayaan dan ventilasi yang memadai berhubungan dengan keberadaan jentik Aedes sp. ${ }^{29}$ Demikian juga hasil penelitian Anwar di Samarinda menunjukkan ada hubungan antara pencahayaan terhadap CI. ${ }^{30}$ Namun demikian, hasil penelitian Sukowinarsih menunjukkan hasil berbeda yaitu intensitas pencahayaan tidak berhubungan dengan kejadian DBD di wilayah kerja Puskesmas Sekaran Kota Semarang. ${ }^{31}$ 
Berdasarkan data dari Dinas Kesehatan Kota Semarang, peran surveilans ABJ seperti Semantik dan Gasurkes di wilayah Kota Semarang tampak sangat penting dalam penyediaan data valid ABJ sehingga keberadaan jentik dapat diantisipasi. Kelemahan kinerja gasurkes dan semantik ini adalah tidak dapat memantau semua rumah yang ada tiap RT secara rutin setiap minggunya. ${ }^{32}$ Sehingga keberadaan jentik nyamuk masih berpeluang ditemukan di rumah yang tidak diperiksa petugas surveilans. Permasalahan klasik dalam setiap pemeriksaan jentik adalah rumah tertutup dan rumah yang enggan menerima petugas pemeriksa jentik meski berseragam. Akibatnya, rumah-rumah tersebut lepas dari pengawasan. Sebagaimana hasil penelitian Sugiyanto pada kader di Kecamatan Ngaliyan Kota Semarang menunjukkan kendala penyuluhan tentang DBD yaitu waktu terbatas, sulit bertemu warga, serta media terbatas. ${ }^{19}$

Meski dianggap kurang optimal, keberadaan Gasurkes dan Semantik di Gasurkes Kota Semarang nampak sangat berperan dalam penurunan kasus DBD selama kurun waktu 2015 sampai dengan 2018 serta mampu membina kerjasama dengan masyarakat dalam pelaksanaan PSN. ${ }^{13}$ Hasil penelitian Putri et al. menunjukkan bahwa efektifitas Gasurkes terhadap output penilaian ABJ hanya sebesar $77 \% .{ }^{20}$ Hasil penelitian Wardayani tentang penilaian kinerja Gasurkes DBD di Kecamatan Tembalang Semarang menunjukkan pencapaian kinerja Gasurkes DBD di Kecamatan Tembalang masih belum mencapai target sesuai dengan yang ditetapkan oleh Peraturan Walikota yang berlaku, terdapat kekurangan pencapaian target sebanyak 5-10\% setiap bulannya, ditemukan juga bahwa disiplin waktu kerja Gasurkes DBD di Kecamatan Tembalang masih belum maksimal, hal ini terbukti dari ditemukannya pelanggaran waktu kerja oleh Gasurkes DBD, selain itu disiplin laporan Gasurkes DBD di Kecamatan Tembalang masih belum sesuai dengan aturan yang berlaku karena masih banyaknya Gasurkes DBD yang terlambat dalam pengumpulan laporan bulanan ke tingkat Kecamatan sehingga menyebabkan keterlambatan laporan di tingkat Kota, meski dalam hubungan dengan ketelitian, Gasurkes DBD di Kecamatan Tembalang masih tergolong cukup baik dengan masih wajarnya kesalahan yang dibuat dalam proses penyusunan laporan bulanan yang memerlukan tingkat ketelitian yang tinggi mengingat banyak form yang wajib dilampirkan dalam laporan tersebut. ${ }^{11}$

Implementasi secara penuh Perda Kota Semarang Nomor 5 Tahun 2010 tentang Pengendalian Penyakit Demam Berdarah Dengue sangat dibutuhkan. Pada pasal 6a dan 6b menyebutkan bahwa warga masyarakat mempunyai kewajiban berperilaku hidup bersih dan sehat, serta menjaga dan memelihara lingkungan sekitarnya dengan cara berperan aktif melakukan pemberantasan sarang nyamuk, sehingga tidak ada jentik nyamuk Aedes sp. di rumah dan pekarangannya. ${ }^{10,33}$ Berdasarkan Perda ini, masyarakat diwajibkan untuk dapat dengan sadar melakukan PSN DBD dan menjaga lingkungannya sendiri agar terhindar dari jentik atau nyamuk DBD. Kegiatan pemantauan jentik dan siapa saja yang melakukan akan menentukan rutinitas kegiatan pemantauan jentik. Berdasarkan Petunjuk Pelaksanaan Perda No.5 tahun 2010 yang tertuang dalam Peraturan Walikota Semarang No 9 Tahun 2015 telah dijabarkan rencana kinerja Pemerintah Kota Semarang salah satunya dalam bidang pengendalian DBD, dijelaskan bahwa pengendalian DBD akan melibatkan masyarakat, pemerintah Kecamatan dan Kelurahan serta Dinas Kesehatan yang diwakili oleh Petugas Surveilans Kesehatan (Gasurkes) DBD.

Keberhasilan pengendalian kasus DBD dipengaruhi juga oleh komitmen stakeholder di wilayah tersebut dalam memperhatikan faktor-faktor yang mempengaruhi hasil pemeriksaan jentik rutin/ nilai ABJ. Seperti contoh kasus DBD yang menurun di Kelurahan Sendangmulyo Kecamatan Tembalang. Kelurahan yang dulu 
termasuk wilayah dengan jumlah kasus DBD tertinggi di Kecamatan Tembalang, kini jumlah kasusnya semakin menurun. Hasil penelitian Putri menunjukkan keberhasilan implementasi kebijakan pengendalian DBD di Kelurahan Sendangmulyo disebabkan oleh adanya komunikasi yang efektif antara Lurah dan kader jumantik, ketersediaan sumber daya manusia yang memadai, dan adanya komitmen dari Lurah dan masyarakat untuk menurunkan angka kasus DBD. ${ }^{34}$ Hasil ini juga didukung penelitian Iswanty bahwa kerjasama stakeholder di wilayah kecamatan Tembalang terkait implementasi kebijakan pengendalian penyakit Demam Berdarah Dengue pada kelompok kerja operasional (pokjanal) DBD di kecamatan Tembalang secara keseluruhan dinilai telah berhasil dengan output kinerja tim pokjanal yang baik dan berpengaruh positif pada outcome yaitu turunnya angka kesakitan DBD hingga $76 \%$ dalam waktu setahun. ${ }^{35}$ Penelitian lainnya di wilayah yang sama yaitu dari Nuraini menunjukkan keberhasilan implementasi kebijakan pengendalian DBD di Puskesmas Kedungmundu dipengaruhi empat variabel, yaitu komunikasi yang baik antara tim gerak cepat pengendalian DBD dengan masyarakat, kuantitas yang cukup dan kualitas yang masih perlu ditingkatkan, serta disposisi yang berjalan sesuai dengan Perda No.5 Tahun 2010 tentang pengendalian DBD dan struktur birokrasi yang sudah baik. ${ }^{36}$

\section{KESIMPULAN}

Hasil identifikasi faktor perilaku masyarakat yang berhubungan dengan hasil positif/negatif pemeriksaan jentik pasca adanya petugas surveilans ABJ (Semantik dan Gasurkes) di Kecamatan Tembalang Kota Semarang adalah perilaku melakukan pemantauan jentik secara rutin di dalam dan di luar rumah. Keterlibatan masyarakat dalam pemeriksaan jentik secara rutin sangat penting mengingat faktor risiko keberadaan jentik yang berhubungan dengan kejadian DBD di Kecamatan Tembalang, yaitu keberadaan kontainer tanaman hias di sekitar rumah dan kurangnya pencahayaan rumah.

\section{SARAN}

Pemerintah Kota Semarang dan Dinas Kesehatan Kota Semarang perlu mengadakan bulan khusus pemberantasan sarang nyamuk (PSN-3M Plus) yang melibatkan semua lapisan masyarakat dan lintas sektor khususnya di bulan-bulan saat pancaroba dan curah hujan tinggi. Bulan khusus PSN-3M Plus akan membudayakan pemeriksaan jentik oleh masyarakat dan lintas sektor secara rutin sehingga dapat meningkatkan kewaspadaan masyarakat terhadap keberadaan jentik nyamuk penular DBD.

\section{UCAPAN TERIMA KASIH}

Terima kasih penulis ucapkan kepada Kepala Badan Penelitian dan Pengembangan Kesehatan dan Kepala Balai Besar Litbang Vektor dan Reservoir Penyakit Salatiga yang telah memberikan kesempatan penulis untuk dapat melaksanakan penelitian ini. Apresiasi kami haturkan kepada Pemerintah Kota Semarang, serta Kepala Dinas Kesehatan Kota Semarang atas kerjasama dan dukungannya dalam pelaksanaan penelitian ini, semoga hasil ini bermanfaat untuk pengendalian DBD di Kota Semarang. Ucapan terima kasih juga kami sampaikan pada teman-teman peneliti dan teknisi yang telah mendukung dalam pelaksanaan penelitian ini.

\section{DAFTAR PUSTAKA}

1. Candra A. Demam berdarah dengue: epidemiologi, patogenesis, dan faktor risiko penularan. Aspirator [Internet]. 2010;2(2):1109. Available from: https://media.neliti.com/media/publications/53 636-ID-demam-berdarah-dengueepidemiologi-patog.pdf.

2. Pusat Data dan Informasi Kementrian Kesehatan RI. Infodatin DBD 2016. Jakarta; 2016.

3. Widiarti, Riyani Setiyaningsih DAP. Implementasi pengendalian vektor DBD di Provinsi Jawa Tengah. J Ekol Kesehat [Internet]. 2018;17(1):20-30. Available from: https://ejournal2.litbang.kemkes.go.id/index.ph p/jek/article/view/116/42. 
4. Dinas Kesehatan Provinsi Jawa Tengah. Profil kesehatan Provinsi Jawa Tengah tahun 2014. Semarang; 2014.

5. Dinas Kesehatan Provinsi Jawa Tengah. Profil kesehatan Provinsi Jawa Tengah tahun 2015 [Internet]. Semarang; 2015. Available from: http://dinkesjatengprov.go.id/v2015/dokumen/ profil2015/Profil_2015_fix.pdf.

6. Dinas Kesehatan Provinsi Jawa Tengah. Profil kesehatan Provinsi Jawa Tengah tahun 2016. Semarang; 2016.

7. Dinas Kesehatan Kota Semarang. Profil kesehatan Kota Semarang 2016. Kota Semarang; 2016.

8. Dinas Kesehatan Kota Semarang. Profil kesehatan Kota Semarang 2017 [Internet]. Semarang; 2017. Available from: http://dinkes.semarangkota.go.id/asset/upload/ Profil/Profil Kesehatan 2016 (OK).pdf.

9. Pujiyanti A, Trapsilowati W. Pelatihan kader dalam pengelolaan kegiatan pemberantasan sarang nyamuk di Kota Semarang. Vektora [Internet]. 2016;8(2):91-8. Available from: https://media.neliti.com/media/publications/12 7205-ID-pembelajaran-kader-dalampengelolaan-keg.pdf.

10. Rakasiwi G, Rengga A. Implementasi peraturan daerah Kota Semarang Nomor 5 Tahun 2010 tentang Pengendalian Penyakit Demam Berdarah Dengue di Kecamatan Tembalang Kota Semarang. J Public Policy Manag Rev [Internet]. 2017;6(2). Available from:

https://ejournal3.undip.ac.id/index.php/jppmr/a rticle/view/15808/15282.

11. Wardayani MO, Widowati N. Penilaian kinerja tenaga surveilans kesehatan (GASURKES) Demam Berdarah Dengue (DBD) di Kecamatan Tembalang Kota Semarang. J Public Policy Manag Rev [Internet]. 2017;6(1):1-14. Available from: https://ejournal3.undip.ac.id/index.php/jppmr/a rticle/view/14565/14090.

12. Jati SP, Sriatmi A, Rahmawati F. Analisis pengendalian penyakit dbd sesuai peraturan daerah Kota Semarang Nomor 5 Tahun 2010 Tentang Pengendalian Penyakit Demam Berdarah Dengue di Kecamatan Tembalang. J Kesehat Masy UNDIP [Internet]. 2016;4(April):10-9. Available from: ttps://media.neliti.com/media/publications/185 47-ID-analisis-pengendalian-penyakit-dbd- sesuai-peraturan-daerah-kota-semarangnomor-5.pdf.

13. Dinas Kesehatan Kota Semarang. Profil kesehatan kota semarang 2018. Kota Semarang: Dinas Kesehatan Kota Semarang; 2018.

14. Khairunisa U, Wahyuningsih NE, Hapsari. Kepadatan jentik nyamuk Aedes sp. (house index) sebagai indikator surveilans vektor demam berdarah dengue di Kota Semarang. J Kesehat Masy [Internet]. 2017;5(5): 906-10. Available from: file://C:/Users/E5/Downloads/19216-38968-1SM.pdf.

15. Nani. Hubungan perilaku PSN dengan keberadaan jentik Aedes aegypti di Pelabuhan Pulang Pisau. J Berk Epidemiol [Internet]. 2017;5(1):1-12. Available from: https://media.neliti.com/media/publications/74 680-ID-none.pdf.

16. Prasetyowati H, Ginanjar A. Maya indeks dan kepadatan larva Aedes aegypti di daerah endemis DBD Jakarta Timur. Vektora [Internet]. 2017;9(1):43-9. Available from: https://media.neliti.com/media/publications/12 7371-ID-gambaran-maya-indeks-dankepadatan-larva.pdf.

17. DitJen PP \& PL Kemenkes RI. Pedoman survei entomologi demam berdarah dengue. [Internet]. Jakarta: Kemenkes RI.; 2013. Available from: https://bbtklppbjb.files.wordpress.com/2016/03 /profil-dbd-untuk-kegiatan-survei-entomologidbd-di-kota-balikpapan-ta-2015.pdf.

18. Taslisia T, Rusjdi SR. Survei entomologi, maya indeks, dan status kerentanan larva nyamuk Aedes aegypti terhadap temephos. J Kesehat Andalas. 2018;7(1):33-41. doi:10.25077/jka.v7.i1.p33-41.2018.

19. Sugiyanto Z, Fani T. Readiness analysis and testing of model on community empowerment for mosquito eradication based online social media to reduce morbidity dengue fever in the District Ngaliyan Kota Semarang tahun 2015. ISBN : 979-26-0280-1 [Internet]. Universitas Dian Nuswantoro Semarang; 2015 p. 477-81. Available from: https://www.academia.edu/26220184/Readines s_Analysis_and_Testing_of_Model_On_Com munity_Empowerment_For_Masquito_Eradica tion_Based_Online_Social_Media_To_Reduce _Morbidity_Dengue_Fever_In_The_District_ Ngaliyan_Kota_Semarang_Tahun_2015?auto= 
download.

20. Putri CRL, Laksono B. Keefektifan petugas surveilans kesehatan demam berdarah dengue dalam menentukan angka bebas jentik. Unnes J Public Heal [Internet]. 2017;6(1):16-23. Available from: https://journal.unnes.ac.id/sju/index.php/ujph/a rticle/view/12452.

21. Sugiyanto Z, Nurjanah, Kurniadi A. SMS Gateway untuk edukasi dan monitoring demam berdarah dengue di Kota Semarang. Seminar Nasional Teknologi Informasi \& Komunikasi Terapan, Semarang 15 November 2014. 2014:74-80.

22. Sumantri R, Hasibuan $P$, Novianry V. Hubungan pemberantasan sarang nyamuk (PSN) dan kebiasaan keluarga dengan kejadian demam berdarah dengue (DBD) di Kota Pontianak tahun 2013. J Mhs PSPD FK Univ Tanjungpura [Internet]. 2014 [cited 2015 Dec 4];1(1). Available from: http://jurnal.untan.ac.id/index.php/jfk/article/vi ewFile/7844/7936.

23. Jaya DM, Ibrahim E, Anwar. Hubungan pemberantasan sarang nyamuk (PSN) DBD dengan keberadaan larva Aedes aegypti di wilayah endemis DBD Kelurahan Kassi-Kassi Kota Makassar [Internet]. Available from: http://repository.unhas.ac.id/bitstream/handle/1 23456789/6168/Dewi Mustika Jaya K11109332.pdf? sequence $=1$.

24. Rini AS, Efendi F, Misbahatul E. Hubungan pemberdayaan ibu pemantau jentik (Bumantik) dengan indikator keberhasilan pemberantasan sarang nyamuk (PSN) di Kelurahan Wonokromo Surabaya. Indones J Community Heal Nurs. 2012;1(1):10. doi: 10.20473/ijchn.v1i1.11883.

25. Ariyati IS. Hubungan antara perilaku PSN (3M Plus) dan kemampuan mengamati jentik dengan kejadian DBD di Kelurahan Tembalang Kecamatan Tembalang Kota Semarang [Skripsi]. Semarang: Universitas Negeri Semarang; 2015.

26. Sudjanal P. Diagnosis dini penderita demam berdarah dengue dewasa. Bul Jendela Epidemiol [Internet]. 2010;2:21-215. Available from: file:///C:/Users/E5/Downloads/buletin-dbd.pdf.

27. Sukana B. Pemberantasan vektor DBD di Indonesia. Media Litbangkes [Internet]. 1993 [cited 2017 Feb 6];3(1):9-16. Available from: http://ejournal.litbang.depkes.go.id/index.php/ MPK/article/viewFile/929/1585.

28. Astuti P, Lustiyati ED. Hubungan kondisi lingkungan fisik terhadap tingkat kepadatan larva Aedes sp. di sekolah dasar wilayah Kecamatan Kasihan, Bantul, DI Yogyakarta. J Ilmu Kesehat Masy. 2018;9(3):216-25.

29. Lagu AMHR, Damayati DS, Wardiman M. Hubungan jumlah penghuni, jumlah tempat penampungan air dan pelaksanaan 3M Plus dengan keberadaan jentik nyamuk Aedes sp. di Kelurahan Balleangin Kecamatan Balocci Kabupaten Pangkep. Higiene [Internet]. 2017;3(1):22-9. Available from: http://journal.uin-

alauddin.ac.id/index.php/higiene/article/downl oad/2760/2605.

30. Anwar A, Rahmat A. Hubungan Kondisi lingkungan fisik dan tindakan PSN masyarakat dengan container index jentik Ae. aegypti di wilayah buffer Bandara Temindung Samarinda. Higiene [Internet]. 2015;1(2):116123. Available from: http://journal.uinalauddin.ac.id/index.php/higiene/article/viewFi le/1242/1227.

31. Sukowinarsih TE, Cahyati WH. Hubungan sanitasi rumah dengan angka bebas jentik Aedes aegypti. J Kesehat Masy [Internet]. 2010;6(1):30-5. Available from: https://media.neliti.com/media/publications/25 298-ID-hubungan-sanitasi-rumah-denganangka-bebas-jentik-aedes-aegypti.pdf.

32. Salsabila N, Raharjo BB. Kinerja petugas surveilans kesehatan dalam penanggulangan demam berdarah dengue. HIGEIA. 2018;2(2):260-71. doi: 10.15294/higeia.v2i2.18854.

33. Novalia RF. Analisis implementasi Peraturan Daerah Kota Semarang nomor 5 tahun 2010 tentang pengendalian penyakit demam berdarah dengue (DBD) di Puskesmas Kedungmundu [Skripsi]. Semarang: Universitas Negeri Semarang; 2016. Available from: https://lib.unnes.ac.id/28129/1/6411412107.pd f.

34. Putri RT, Sudiro, Ratna L. Analisis implementasi kebijakan pengendalian demam berdarah dengue di Kelurahan Sendangmulyo Kecamatan Tembalang Kota Semarang. J Kesehat Masy [Internet]. 2012;1(2):108-17. Available from: http://ejournals1.undip.ac.id/index.php/jkm. 
BALABA Vol. 15 No. 2, Desember 2019: 91-104

35. Iswanty A. Analisis implementasi kebijakan pengendalian demam berdarah dengue (DBD) di Kecamatan Tembalang Kota Semarang. J Kesehat Masy [Internet]. 2012;1(2):1-5. Available from: https://media.neliti.com/media/publications/18 813-ID-analisis-implementasi-kebijakanpengendalian-demam-berdarah-dengue-dbd-di- kecama.pdf.

36. Nuraini S. Analisis implementasi kebijakan pengendalian demam berdarah dengue di Puskesmas Kedungmundu Kecamatan Tembalang Kota Semarang. J Kesehat Masy [Internet]. 2012;1(2):118-25. Available from: http://eprints.undip.ac.id/38618/1/4456.pdf. 